Miscellanea Anthropologica et Sociologica 2019, 20(1): 98-114

Wojciech Starzyński ${ }^{1}$

\title{
Irena Krońska: A Student and a Critic of Roman Ingarden's Philosophy
}

In this article on Irena Krońska (1915-1973) I attempt to present three stages in her approach towards the philosophy of Roman Ingarden. The first one may be associated with her review in Revue philosophique de France et de létranger of 1949, printed following the publication of the Controversy over the Existence of the World, Volume 1. The second one encompasses the period up to 1968 when Krońska was cooperating with Ingarden. The third one covers the period after Ingarden's death in 1970 and provides an assessment of his work, largely in the framework of correspondence between Krońska and Patočka. I maintain that Krońska was consistent in her criticism, voiced from the perspective of Phenomenology, inasmuch as she disapproved of Ingarden's ontologicism and sense of "positivism" that was in his removedness and lack of ethic-existential content which for Krońska constituted the essence of philosophy.

Key words: Irena Krońska, Roman Ingarden, Jan Patočka, Polish phenomenology

\section{Introduction}

The following article aims to address the problem of Irena Krońska’s philosophical position and its relation to Polish phenomenology, in particular to determine what was the character of Krońska's critique of Roman Ingarden's thought. How is it possible that a person one could hardly call a phenomenologist, for her few published works dealt primarily with Greek philosophy, exerted such a remarkable impact on Polish phenomenology? It seems that the thesis could be cautiously supported twofold. To start with, Krońska was the very first philosopher who framed a critical line of interpretation of Ingarden's philosophy, whereby - in contrast to a violent critique put forward a few years later by her converted to Marxism

\footnotetext{
1 Institute of Philosophy and Sociology, Polish Academy of Sciences; wstarzyn@ifispan.waw.pl.
} 
husband, Tadeusz Kroński (see Kroński 1952) - she adopted a phenomenological stance. Secondly, her standpoint, though autonomous, still, was shaped by relationships with Polish philosophers like Tadeusz Kroński and Leszek Kołakowski, but also and primarily, by an extraordinary exchange of letters with Jan Patočka. The correspondence with the latter definitively proves that Krońska was in favour of the phenomenological philosophy, however, alternative to that proposed by Ingarden. Central to the problem at hand, for consideration here, is consequently the history of relationships between Krońska and Ingarden. Of particular interest is the criticism of Ingarden's thought, voiced in several publications, the wider context of which has been studied with respect to a longstanding correspondence between Krońska and Ingarden. The exchange of letters between them allows for an understanding of Krońska’s stance more easily and comprehensively.

\section{Krońska's review of Ingarden's Controversy over the Existence of the World}

At this point, I shall remind that Krońska, nee Krzemicka, was born in 1915 and during 1933-37 she was a student of classical philology and philosophy at the Jan Kazimierz University in Lvov. This is where she met Ingarden, who was her first professor of philosophy. Ingarden inspired in the young student an interest in phenomenology and despite the fact that it was classical philology that was her major, we could risk a claim that during her Lvov studies Krońska became de facto a philosopher-phenomenologist. Further personal developments in her life enabled her to become independent of the influence of Ingarden's thought: upon graduation, Krzemicka left Lvov, moved to Warsaw, married Tadeusz Kroński, who introduced her to Patočka who became their mutual friend. Krzemicka's first publication (on the translation of philosophical texts) backs up the statement. The text was published owing to Patočka, who translated the work into Czech (Krzemicka 1938). Krzemicka employs there a combination of Ingarden's and Husserl's method with the ideas presented in Husserl's Logische Untersuchungen, what on the one hand proves her thorough knowledge of Ingarden's thought, and on the other hand, demonstrates her gaining research independence. Also written in April 1939, Krzemicka's letter to Patočka shows a great enthusiasm of the young student to get acquainted with the latest publications by Husserl, Fink or Landgrebe, as well as to combine the perspectives of phenomenology and ancient Greek philosophy (see Krzemicka 1939). During World War II, Mr. and Mrs. Kroński - both of Jewish origin - managed to escape the jaws of death at the hands of the Nazis, and following being held in a prisoner of war camp, they ended up in Paris. There, Krońska became familiar with new philosophical currents, with 
Sartre's and Heidegger's philosophies to the fore. She did not stop, however, tracking what is going on in Polish philosophy. With the first volume of the Controversy over the Existence of the World published in 1947, Krońska prepared its review for the journal Revue philosophique de France et de létranger (Krońska 1949). Ingarden was clearly impressed with its style and content and in a letter as of 14 April 1949 he wrote:

Dear Mrs. Krońska, in these days, I have received the most recent volume of Revue philosophique where we read your article on the first volume of the Controversy over the Existence of the World. (...) I shall thank you for the article. In my opinion it is well-written, quite rightly (with minor flaws) informing about the content of the book, serious, with no compliments, and at the same time addressing in a critical manner some aspects we could argue about. I also think it did not come easily to write the article and the very fact you have managed to write it in this form is very much to your credit and to the credit of your work over the last years (Ingarden 1949). ${ }^{2}$

How can we characterize the criticism of Ingarden's main work? In the text discussed here, Krońska places Ingarden among authors such as Sartre, Heidegger or Nicolai Hartmann. The thought of each of them emerged in reaction to the idealistic turn in Husserl's philosophy. Ingarden opposed Husserl in that he developed phenomenological "realism." Krońska refers to Ingarden's viewpoint, original and autonomous, as she underlines it, as to plural realism. This form of realism would preserve as basic to the phenomenological method, together with its epoché, and would distance itself from Husserl's transcendental reduction, deemed unacceptable. Phenomenology, therefore, would concern "validation," understood as "doing justice" to things as they appear in all their heterogeneity and complexity, rather than "reduction." As opposed to the philosophers mentioned above, Ingarden fulfils this requirement abiding by a kind of methodological minimalism, which Krońska links to Husserl, previously postulating for phenomenology as a rigorous science (strenge Wissenschaft). This link, in turn, leads Krońska towards describing Ingarden's position as a special type of "positivism." From that moment, such a qualification of Ingarden's philosophy would be reflected in all of her analyses of the thought of the author of the Controversy over the Existence of the World.

This rather enigmatic accusation may seem odd, considering that it was Ingarden in the mid-1930s that strongly criticized neo-positivism, represented by the

\footnotetext{
2 "Droga Pani, doręczono mi w tych dniach ostatni zeszyt Revue Philosophique, w którym znajduje się artykuł Pani o I t. Sporu. (...) Za artykuł Pani bardzo dziękuję. Uważam, że jest dobry, tzn. trafnie (z drobnymi wykolejeniami) informujący o treści książki, poważny, bez komplementów, a zarazem poruszający krytycznie pewne punkty, co do których można dyskutować. Sądzę też, że artykuł ten nie było łatwo napisać i to, że Pani go w tej postaci zdołała napisać, dobrze świadczy o Pani i Pani pracy w ostatnich latach."
} 
Vienna Circle, referring himself also to similar tendencies noticeable within the Lvov-Warsaw school. What is worth noting, Krońska is perfectly aware that it is not about this kind of positivism, but about a certain form of it implemented into phenomenology. She gives the difference by taking the term in quotes ("positivism"), although she also freely refers to a positivist formula that Ingarden concludes with one of his texts: "that positive facts, given in all valid experience, should be simply taken into account" (Ingarden 1963a: 654). In the 1949 text, the accusation of positivism is reduced to the statement that with the problem of the existence of the world as a point of departure, Ingarden considers it as a relationship between the world and consciousness, thus developing a theory he denotes as existentialontological analysis. According to Krońska, the ontologization of phenomenology would result in a change of the object of considerations - no longer would that be phenomena as such but rather modes of existence, an analysis of which encourages considerations about different existential moments. Philosophy comes to be considered as a reflection on the existential moments, which are grouped in previously exclusive pairs (autonomy-heteronomy, distinctiveness-connectiveness, originality-derivativeness, independence-dependence). Krońska notes that these notions introduced by Ingarden are as a matter of fact derived from the notion of dependence/independence, that is, focus not on a phenomenon but rather on a relationship between the phenomenon of consciousness and the world. Ingarden would offer some logicism here, for it appears that ontological aspects are subject to the laws of logic, in particular, logical consistency, which becomes the key to differentiating between the basic notions. Subsequently, the concept of existential ontology is further developed in that listed are all possible combinations of existential moments. As Krońska observes, the result is a somewhat awkward thesis about "19 possible modes of existence for the 'world"' (Krońska 1949: 223). The possibilities are then subject to temporal analysis, which introduces the following existential moments: actuality, post-actuality, and fissurative character.

Krońska concludes her review with a discussion of the possibility of solving the eponymous controversy. Ingarden sees it in the transition from ontological analyses to metaphysics. He approaches metaphysics as a discipline which, after preliminary ontological analyses, considered from the perspective of possibilities, shifts to the reality, still within the limits established by ontology. We shall keep in mind, however, that, according to Krońska, the preference of ontology is linked to the primacy of logic, for ontology is based on the rule of logical consistency, which allows for the introduction of contradictory word pairs. In other words, if Ingarden's ontology described the concept of a possible world as previously complying with the rule of logical consistency, Ingarden would be guilty of logicism, in that he would fail to subject his basic assumption for validation procedure. 
Ingarden denies the accusations, curiously enough without offering any arguments. In a letter to Krońska of 14 April 1949, he writes:

As for what came to my mind during reading, I feel like we should discuss this in person, not in a letter. Let me only indicate the issues: in your presentation of my views, the thesis that I understand existential moments relatively is wrong. I am inclined to believe an analysis of the concept of a relationship in volume 2 supports my stance. Furthermore, the idea that there are 19 possible ways of the world's existence is wrong (the 19 ways refer to the coexistence of the world and pure consciousness). Also, I cannot agree with the statement that ontology in my works is based on logics. I did not address the problem in the Controversy I, but it is vivid in Essentiale Fragen, where the logical theses are clearly based on relevant ontological (formal) ones. The misunderstanding here lies in basing the assumptions of one science on another one and applying in scientific considerations the laws of logic being two different aspects. It is beyond any doubt that in my considerations I do apply the laws of logic but never as indicators of ontological assumptions.

I think I have listed the most important problems. (...) Whether we shall resign the laws of logic within ontology is disputable, crucial when considering the issue of the theory of knowledge, this I admit.

Anyway, I do consider your article well-written and I doubt it anyone in Poland could excel you at writing one (Ingarden 1949). ${ }^{3}$

Despite this prelude to a more detailed discussion, no track of its continuation is left, which does not imply, however, that the relationship between Krońska and Ingarden did not continue. However, it should be emphasized that a very unfavorable historical circumstances accompanied the reception of Ingarden's main work in post-war and communist Poland. It has to be recalled that Kroński himself had seemed to identify with phenomenology from the early thirties, among others publishing in Przeglad Filozoficzny and Ateneum, two reviews of Ingarden's Das literarische Kunstwerk (Kroński 1933, 1938). As we learn

3 "Co do poszczególnych kwestii, które mi się nasunęły podczas czytania, to trzeba zdaje się pomówić i w liście nie da się tego załatwić. Ograniczając się do wymienienia samych kwestyj, powiem: w przedstawieniu moich poglądów nie jest słuszna teza Pani jakoby momenty egzystencjalne były pojęte przeze mnie relatywnie. Myślę, że analiza stosunku w II t. potwierdza moje stanowisko. Niesłuszne jest także, że istnieje 19 możliwych sposobów istnienia świata (te 19 sposobów dotyczy współistnienia świata i czystej świadomości). Zarzut, że ontologia jest u mnie oparta na logice nie jest słuszny. W Sporze I nie wypowiadałem się na ten temat, widać to jednak w Essentiale Fragen, gdzie wyraźnie tezy logiczne oparte są na odpowiednio dobranych ontologicznych (formalnych). Nieporozumienie wynika stąd, że co innego jest opieranie się twierdzeń jednej nauki na drugiej, a co innego stosowanie się w rozważaniu naukowym do praw logiki. Otóż ja się w rozważaniach niewątpliwie stosuję do logiki, ale nie używam ich jako przesłanek twierdzeń ontologicznych.

To chyba najważniejsze sprawy. (...) Czy w ramach ontologii należałoby zawiesić ważność praw logiki - to jest kwestia do dyskusji. Kwestia ta wchodzi bardzo poważnie w rachubę w rozważaniach teorii poznania, na to się oczywiście piszę.

W każdym razie uważam artykuł Pani za dobry i - myślę - że w Polsce nikt lepszego nie napisze." 
from the recently issued several letters of Kroński to Patočka, in 1939, as a result of tense relations with his supervisor prof. Tatarkiewicz, Kroński intended to move to Lvov and complete his doctoral thesis under the direction of Ingarden. In a letter from February 2, we read: "I am very scared now, what you [J. Patočka] and Prof. Ingarden will say about my article ... The article on Husserl by Prof. Ingarden in Przeglad Filozoficzny will be published soon. Tatarkiewicz is very angry for that reason and I will be happy when I will be able to go to Ingarden to Lvov!" (Kroński 1939). It seems that at least until his important essay on Fascism and the European Tradition (Kroński 1960), written in 1942-43, he was still using the phenomenological method, and the violent transition to Marxist positions occurred after the war during his stay in Paris. In 1949, the Kroński family decided to return to Poland, where Tadeusz Kroński became an influential philosopher-intellectualist and professor actively supporting Stalinism. In this attitude, but also to confirm his usefulness for the new regime and to dismiss any suspicion on the part of the communist authorities (he was denied membership in the party), he published in 1952 his review of the Controversy over the Existence of the World, where he formulated the allegation of "realistic idealism" against the author, and he assessed the book itself as "an example of infertility, decay and bankruptcy of contemporary bourgeois philosophy" (Kroński 1952: 331). By juxtaposing two reviews, one can get the impression that Kroński was using in some way the objections formulated three years earlier by Krońska, however, within his strange rhetoric and to achieve his new ideological goals. In the said period from 1950 to 1956, Ingarden was sent by the authorities' decision to a forced leave, without any possibility of teaching at the university, he was also banned from publishing his phenomenological work, however, he was not deprived of his livelihood, being involved in translation and publishing work. And it was in these circumstances that a new cooperation was established between Krońska, now as wife of a prominent professor and degraded and in some way humiliated until 1956, Ingarden.

\section{Cooperation of Krońska and Ingarden}

Starting from 1951, their cooperation based chiefly on publishing the series "Biblioteka Klasyków Filozofii" (BKF) ["Library of the Classics of Philosophy"]. Krońska was its Editor-In-Chief, whereas Ingarden was on the Editorial Board. The situation is normalized in 1957, when Ingarden returns to the university, in the meantime in 1958 Kroński suddenly dies. At that time, they communicated mainly by means of letters, since Ingarden was living and working in Krakow and Krońska in Warsaw. They focused on current editorial projects. Nevertheless, 
Ingarden did not cease to underline Krońska's credit to Polish philosophy on the one hand, and on the other hand, he did not cease to regret she failed to pursue an academic career. When referring to the post-war lives of his students in a letter of 8 March 1963, Ingarden writes:

I did have a certain hope that you will defend your dissertation in Paris, and then you came back to Poland and things turned out differently. It could not be helped. Somehow the most able of my colleagues and friends who could influence Polish philosophy, like Alexander Rosenblum, Ignacy Wasserberg, Alfons Baron, and among them, yourself, failed to follow formalities. Your activity in the "Library of the Classics of Philosophy" will certainly mark Polish culture, this I do not forget, but your great philosophical skills could have predisposed you to an altogether different role (Ingarden 1963b). ${ }^{4}$

On a different occasion, Ingarden advances even a kind of philosophical reflection on Krońska's case, on the one hand, deliberating upon her unfulfilled philosophical talent, and on the other, taking into consideration her substantial contribution to Polish culture through her work on the series of the "Library of the Classics of Philosophy" and over 100 volumes published.

I think that in the various unforeseen or anticipated bad events and processes which happen in every age - one should keep faith in the value of the work we have devoted to life. If not today, then sometime in the future positive and creative work will bring positive results, perhaps late, when we will not see it ourselves, but all productive work settles down slowly in human culture. What you have done over a dozen years for the culture of Polish philosophy is certainly a lasting value, the significance of which will be seen in the future. I have often admired your perseverance and not lowering the requirements for the quality of work, that is, the selection and quality of translations that you released for the BKF, and I also admired how much you have learned over the years in terms of philosophy, in its extremely manifold manifestations, and how great you have gained the ability to understand the author's tendencies and the problems of various positions. It will not be lost either. So although it is difficult, and must be, for people who have a significant cultural importance in the intellectual life of their era - one must keep on with the same eagerness that we can see in you and realize a tasks that you have always guided. Once in Paris in 1946, you told me that you survived the war only because you were philosophers. I formulated something similar in the form of

\footnotetext{
4 "Miałem jeszcze pewną nadzieję, że uzyska Pani doktorat w Paryżu, ale niestety przed końcem powróciła Pani do Polski - no i wszystko się inaczej potoczyło. Ale trudno. Jakoś tak się dziwnie składało, że szereg najzdolniejszych moich kolegów i przyjaciół, którzy mogli wpłynąć na los filozofii polskiej - jak np. Aleksander Rosenblum, Ignacy Wasserberg, zapoznany w swych szczególnych talentach Alfons Baron itd., a min. i Pani, jakoś nie zdołali załatwić spraw formalnych. Pani działalność w BKF pozostanie niewątpliwie w kulturze polskiej i o tym nie zapominam, ale Pani wielkie zdolności także w zakresie filozofii mogły Panią predysponować do zupełnie innej roli.”
} 
transformation of an old saying. I said: primum philosophari, deinde vivere. I think that we should stay with it (Ingarden 1967). ${ }^{5}$

Convinced of Krońska’s exceptional abilities, Ingarden comes up with an idea for writing together with her volumes encompassing Ingarden's lectures on ethics and aesthetics and publish these under their names. "You will manage perfectly - writes Ingarden in a letter of 16 January 1966 - and maybe you will even find it interesting enough to elaborate on the problems only briefly outlined so that it would not be solely editing" (Ingarden 1966). ${ }^{6}$ Krońska accepts the offer, but the work had to be deferred in time till current obligations were met. In the end, the project was dismissed. 1968 sees Anti-Jewish campaigns in Poland and Krońska may no longer occupy the position of the editor of the "Library of the Classics of Philosophy" (BKF). She is summarily dismissed from the publishing house. In addition, all printed copies of the II volume of the Dictionary of Philosophers that Krońska was preparing at the time, by the decision of the authorities, were destroyed.

Initially, immediately after Krońska’s dismissal, Ingarden reacts vehemently and writes a letter to Krońska:

It is with great sadness that I learned about your fate. I deem it a complete failure of the "Library of the Classics of Philosophy" and I do not hope for it, rebus sic stantibus, to continue to exist. This constitutes an irretrievable loss for Polish culture. A comparably irretrievable loss is the Dictionary. I deeply regret it happened, being also concerned about how you will now manage to do it. (...) I send you

\footnotetext{
5 "Myślę, że w różnych nieprzewidzianych lub przewidywanych niedobrych zdarzeniach i procesach - które w każdej epoce się zdarzają - należy zachować wiarę w wartość pracy, której poświęciliśmy życie. Jeżeli nie dziś, to kiedyś w przyszłości praca pozytywna, twórcza, przyniesie dodatnie wyniki, być może późno, gdy już sami tego nie będziemy oglądać, ale wszelka wytwórcza praca osadza się w ludzkiej kulturze powoli. To, co Pani działalnością lat kilkunastu zrobiła dla kultury polskiej filozofii, jest z pewnością wartością trwałą, której doniosłość się jeszcze w przyszłości okaże. Nieraz podziwiałem Pani wytrwałość i nie obniżanie wymogów co do jakości pracy, to znaczy doboru i jakości tłumaczeń, które Pani wypuszczała z redakcji BKF, i podziwiałem też, jak wiele się Pani przez te lata zdołała nauczyć w zakresie samej filozofii, jej nad wyraz rozmaitych przejawów, i jak wielką Pani zdobyła umiejętność rozumienia przeciwstawnych sobie nieraz tendencji autora i problematyki rozmaitych stanowisk. To także nie będzie utracone. Więc jakkolwiek trudno jest i musi być ludziom, którzy mają istotną wagę kulturalną w życiu umysłowym swej epoki - trzeba dalej z tą samą, tak widoczną u Pani, żarliwością realizować zadania, które Pani zawsze przyświecały. Kiedyś w Paryżu w roku 1946 powiedziała mi Pani, żeście przetrwali wojnę tylko dlatego, że jesteście filozofami. Ja sobie coś podobnego inaczej sformułowałem pod postacią przeistoczenia starego powiedzenia. Mówiłem: primum philosophari, deinde vivere. Myślę, że należy przy tym pozostać.”

6 "Pani mogłaby to świetnie zrobić, a przy tym może by to Panią na tyle zainteresowało, żeby Pani wypracowała różne sprawy tylko naszkicowane, tak iż wkład Pani nie byłby tylko redakcyjny."
} 
my kindest regards and wish the situation improves. Should you have any trouble, please let me know, I will be glad help you (Ingarden 1968a). ${ }^{7}$

Krońska replies, clearly reassured with Ingarden's support, but she is soon disillusioned, for Ingarden does not publicly comment on the situation and remains an employee of the "Library of the Classics of Philosophy" In September 1968, he sends an odd letter. Krońska comments on the margin: "Of course, there is no envelope sender header. It is not my intention to reply. No more illusions he [Ingarden] could understand anything beyond his success in life and in the field of philosophy. Amusingly enough, he must have felt stupid, for the letter is clumsily written, with spelling mistakes in it" (Krońska 1968). ${ }^{8}$ Ingarden himself explains in the letter that he came to Warsaw to attend the "Library of the Classics of Philosophy" meeting, but unfortunately did not have time to pay Krońska a visit. "Your friends will probably report to you about the meeting." Krońska notes on the margin: "They have reported, indeed." Ingarden continues: "I was told after the meeting there are plans to give you some translation and editing work, but not to have you on the Editorial Board." Krońska replies in the margin: "How keen I am to start. How he does not understand a thing." Ingarden concludes: "Myself, I have decided to remain [on the Board] to see how the situation develops. As for the time being, I am so tired with all that mess that I intend to go to Rabka" (Ingarden 1968b). ${ }^{9}$

From then on, the correspondence between Krońska and Ingarden comes to a halt. Krońska, disappointed with her "master's" attitude towards the events of 1968, fails to reply to his letters, in which he describes his current affairs, but remains silent about what happened on the Editorial Board. Meanwhile, Krońska's exchange of letters with Patockka greatly intensifies, the two of them united by a somewhat common fate, for Patocka at the time was forced to retire and his publications were blacklisted.

7 „Z wielką przykrością dowiedziałem się o Pani losie. Uważam to za klęskę BKF i nie mam nadziei, rebus sic stantibus, żeby BKF nadal istniał. Jest to niepowetowana strata w stanie dobra kulturalnego polskiego. Także wstrzymanie Słownika [filozofów] nie da się powetować. Ubolewam nad tym. Oczywiście dochodzi do tego troska o to, jak sobie Pani teraz da radę. (...) Serdecznie Panią pozdrawiam i życzę poprawy sytuacji. Gdyby Pani była w kłopotach pieniężnych, proszę mi napisać. Chętnie Pani pomogę."

8 "Na kopercie oczywiście nie było nadawcy. Nie mam zamiaru odpisywać. Przypieczętowany koniec złudzeń, że [Ingarden] mógłby jeszcze cokolwiek rozumieć oprócz swoich sukcesów życiowych, filozoficznych. Zabawne, że pisząc musiało mu być jednak 'łyso,' bo list napisany niezdarnie i z błędami ortograficznymi."

9 "O przebiegu posiedzenia zapewne opowiedzą Pani znajomi. (...) Po posiedzeniu powiedziano mi, iż zamierzają dać Pani różne prace tłumaczeniowe i redakcyjne, ale do Komitetu Pani nie wezmą. Sam na razie postanowiłem zostać do czasu, jak się rozwinie akcja nowych tłumaczeń. Na razie po tych wszystkich jazdach jestem bardzo zmęczony i zamierzam wyjechać do Rabki." 


\section{Krońska and Patočka: Epistolary contacts and new work on Ingarden}

The question of Ingarden's philosophy appears in the correspondence between Krońska and Patočka when, in 1970, at the age of 77, Ingarden dies suddenly and unexpectedly. Both Krońska and Patočka are moved, and Krońska immediately offered condolences to the widow. "I am writing to you, for I cannot recover from the sadness at the news of your husband's death. (...) I consider it a painful and unexpected blow. I belong to these many people who owe a lot to the late Roman Ingarden: I owe him my philosophical initiation. He was the one to introduce me in Lvov in the 1930s to the world I had not known before, but which then became my world" (Krońska 1970a). ${ }^{10}$ In Krońska's letters to Patočka, in turn, we read that just before Ingarden's death, she was willing to write a letter to Ingarden, in which she wished to phrase her bitter remarks on his ethics, so blatantly contrary to his conduct of life.

Under the circumstances, Krońska still felt she had a score to settle with Ingarden. Her perspective in the end was different, but the ideal-philosophical dimension blended with the private sphere.

Ingarden's unexpected death - she writes to her Czech friend - has shaken me deeply both despite of and in view of what you are aware of [the "Library of the Classics of Philosophy" affairs]. He has been a part of my world for years and I cannot accept he no longer is. I feel like writing about him, though for the time being I lack words, I expect it should not take the form of obituaries that have been published recently, all more or less similar and not conveying what is really important.

It is him whom I owe my beginnings as a philosopher - a fact that cannot be forgotten.

In the light of this death, a definite fact, I wish I have not written him in my last letter which I did not feel would indeed be an ultimate one what I have written about to you, my dear Friend. It may be I will write an obituary different from these published in newspapers - I feel an urge to do so, a duty and subjective difficulties (Krońska 1970b). ${ }^{11}$

10 "Piszę do Pani, nie mogąc otrząsnąć się z uczucia przygnębienia po usłyszeniu przed kilkunastu godzinami okropnej wiadomości o zgonie Pani Męża. (...) Jego śmierć odczuwam jako cios nie tylko straszny, lecz całkowicie nieoczekiwany, ze strony przyrody zdradziecki. Należę do osób, które śp. Romanowi Ingardenowi zawdzięczają bardzo wiele: inicjację filozoficzną. To On otworzył przede mną we Lwowie, w latach 30., świat, którego wcześniej nie znałam, a który stał się odtąd moim światem."

11 "La mort, absolument inattendue d'Ingarden m’a profondément bouleversée, malgré tout et avec tout que vous savez. Depuis des années, des décades, il faisait partie de mon monde et je ne peux pas admettre son absence. Je crois que je vais écrire sur lui, me je ne trouve pas encore l'expression, je sens que cela doit être différent des articles nécrologiques qui ont paru ce dernier temps et qui disent à peu près la même chose sans dire la chose. Et c'est à lui que je dois mon initiation philosophique - chose qui ne s'oublie pas. Face à cette mort, fait irréparable, j’aurais préféré ne pas 
Patočka replies to Krońska on 17 July 1970. "I, too, was highly agitated by the news of Ingarden's death. However, opposed to his ideas and conduct of life, we have all lost a real prominent philosopher. This unfortunate time which takes what we hold dear, has taken its toll where least expected. He wrote me a letter, probably two weeks prior to his death, describing all his scientific plans" (Patočka 1970). ${ }^{12}$

In these circumstances, Krońska, in consultation with the Ingarden family, Danuta Gierulanka (Ingarden's research assistant) and the Niemeyer publishing house, undertakes editorial works aimed at publishing the German version of a new volume of Ingarden texts devoted to aesthetics. This project was interrupted by Krońska's disease, and the materials became a basis for the volume Gegenstand und Aufgaben der Literaturwissenschaft: Aufsätze und Diskussionsbeiträge (1937-1964) published several years later (Ingarden 1976). It is probably at that time that Krońska also writes a never published text in French "Lesthétique phénoménologique en Pologne."

During that time, in this emotional climate, an idea emerged among Ingarden's disciples to publish a posthumous volume devoted to Ingarden. Both Patočka and Krońska were invited to contribute, whereby Krońska published another text on Ingarden in the journal Twórczość ['Creative Output'] (Krońska 1971a). This marked a twist in their correspondence, and the reflections on the work of Ingarden now became a recurring topic. In a letter of 9 July 1971, Patočka refers to one of Ingarden's last pieces, the one on Husserl's Crisis (see Ingarden 1970), and expresses his perplexity that Ingarden did not notice the new content present in the late Husserl. He concludes similarly as Krońska does:

If "noetic" analysis surrenders its position almost completely, is it not a fact worthy of being noted? This means that the notion of "subjectivity" has undergone a drastic change. Meanwhile, how "idealization" has come to be understood, has also changed, a fact noted by few critics only, and I regret to say also Ingarden has failed to note that. Just as though the problem of the existence of the external world limited his horizons. I deem it an important problem, I disagree with Heidegger who regarded it as non-existent, but before we proceed to any serious considerations, we shall elucidate from the perspective of phenomenology the notion of the world, external world, and so on (Patočka 1971a). ${ }^{13}$

lui avoir dit dans ma dernière lettre que je ne pressentais pas être dernière dans ce sens définitif, et dans ma lettre précédente adressée à vous, cher Ami, ce que j’y avais dit. Peut-être lui consacrerai-je un article nécrologique différent de ceux qui ont paru depuis dans nos hebdomadaires - je sens le besoin, le devoir et les difficultés subjectives."

12 'La mort d'Ingarden m’a aussi très ému. Malgré tout ce qu’on ait pu objecter à ses idées et son attitude personnelle, nous avons tous perdu un grand et véritable philosophe. Ce temps malheureux qui nous prend tant de choses sest tourné soudain vers une victime quon ne soupçonnait pas. Il mavait écrit quelque 14 jours avant sa mort une lettre où il parlait longuement de ses plans de travail."

13 “Je métonne qu'il n’ait rien trouvé davantage de neuf. Si l'analyse 'noétique' perd presque tout le terrain qu'elle occupait avant, n'est-ce pas là un fait digne de remarquer? Cela signifie en même 
Krońska, in turn, once again chooses to assess Ingarden's work, this time employing a kind of existential analysis that would shed some light on the theoretical content in his philosophy and would thus enable to interpret more broadly his conduct of life. In her reply to Patočka she writes: "At the moment your letter reached me I was just writing on Ingarden to our volume, hence I wanted to have all his books at hand. (...) I undertake to present his stance towards the world, which I think is typical and constitutive of him as a human being and a philosopher and which I believe is reflected in all of his works, including the last article on the Crisis that you have commented upon in your last letter" (Krońska 1971b). ${ }^{14}$

Shortly after Patočka receives this letter, he sends Krońska to translate his article on the criticism of Ingarden's concept of aesthetics (see Patočka 1972). Krońska, in turn, spends some more time working on her texts on Ingarden, and finally sends these to her Czech friend in October 1971. It seems that it is precisely this "Retrospective Fragment" that contains further elements of her 'settlement' with the work and person of Ingarden, elements somewhat blurred, but grasped more easily if one is familiar with the correspondence between Krońska and Patočka.

At this point, let's take a look at how Krońska comes to terms with Ingarden's work. To begin with, Krońska once again undertakes an analysis of Ingarden's positivism, its purpose being to indicate these elements of his thought which added to the existential leaning of his philosophy. She finds such elements in the concluding sentences of the French version of Ingarden's Man and His Reality (Ingarden 1960). The initial version of the text, a radio speech dating back to 1939, described the world as such built upon fundamental values of the good, the truth, and the beauty. The version of the text written right after World War II presents a human being on the border of two worlds: that of a human and that of an animal. Ingarden writes about the tragic in human experience, which manifests the true nature of human life: the genius and the futility of existence. The tragedy of human condition demonstrated in such a way does not make Ingarden reformulate his philosophy. As Krońska puts it, he used a language more emotional than usually, but he wrote in the same spirit as in the Controversy over the Existence of the World.

temps que la notion de 'subjectivité a changé profondément. Et la manière dont l'idéalisation' est conçue, a subi aussi des modifications que peu de critiques ont remarquées - je regrette d'avoir à constater que c'est aussi le cas d'I. C'est que le problème de l'existence du monde extérieur barre tout son horizon. Je crois que c'est un problème important, je ne le considère pas comme inexistant à la façon de Heidegger, mais il serait bon d’éclaircir phénoménologiquement cette notion du monde, monde extérieur etc. avant de passer aux considérations constructives."

14 "Au moment de l'arrivée de votre lettre jétais en train d'écrire sur Ingarden pour notre revue, donc je préférais avoir tous ses ouvrages sous la main (...) J'y tâche de montrer un trait d'attitude envers le monde qui me semble caractéristique et constitutif pour Ingarden en tant qu'homme et philosophe, et que l'on trouve, à ce qu'il me semble, dans tous ses ouvrages, aussi dans le dernier article sur la Krisis que vous avez interprété parfaitement dans votre dernière lettre." 
Similarly, Krońska unveils Ingarden's bewilderment with what was told him by Husserl, for whom philosophy is not only a mission and vocation, but also means of offering rescue to the one suffering the tragedy of his existence. Krońska argues that Ingarden was amazed, for the thought was unfamiliar to him as a "Positivist," yet he experienced it himself when in Lvov during World War II he plunged into work on the Controversy over the Existence of the World. Ingarden alone expresses in the introduction to his magnum opus that the war did not have a solely negative influence on the book. "The true face of war was revealed fully mainly in Poland; the war had to be endured, the war had to be won with an inner spiritual attitude, what, in turn, required fortitude and courage in every sphere of activity as well as unswerving moral stance. (...) It was my struggle for these that allowed me to survive through this period" (Ingarden 1987a: 12). Therefore, "extreme situations" Ingarden was faced with, as Krońska mentions, do emphasize even more strongly the main line in Ingarden's philosophy, namely how he approached positivism, understood in a such way that "positive states of things, learnt through a relevant experience, shall be accepted" (Krońska 1971a: 89; Ingarden 1963a: 654). This could easily be juxtaposed with a radical opposition to Husserl's reduction.

Krońska's article is enthusiastically received by Patočka, who fully agrees with the thesis concerning Ingarden's positivism. In a letter of 23 October 1971, he writes: "I have just read a remarkable article you have written about Ingarden. I am impressed both with its depth and form. You have managed to write his portrait being neither too academic nor too literary - the result is Ingarden himself, it's really him, this is how I still see him. He was a prominent philosopher, a Positivist, in your understanding of the term, with no desire to amend the world (...)."15 Patočka saw Ingarden's positivism manifested through a certain anti-speculative scepticism that would cover under-realized and under-elucidated ontological assumptions, which were decisive of the whole of his philosophy. Patočka believes "Ingarden was faithful to anti-speculative philosophy and suspected that Husserl, and even more so, Heidegger allow for speculation. But, then, does not his own 'ontology' lack the necessary basis? His aim is to adopt ontological reasoning. The question is, what 'to be' means for Ingarden. How does he evaluate what is and what is not?"16 According to Patočka, Ingarden's positivism transpires also in the

15 "Je viens de lire le bel article consacré par vous à Ingarden. Le fond et la forme mont beaucoup impressionné. Vous avez su brosser de lui un portrait vrai sans donner dans l'académisme ni dans le jargon 'littéraire' - c'est bien lui, tel que je le vois devant moi. C'était un philosophe remarquable, positiviste au sens que vous dites, ne voulant pas projeter des programmes de réforme du monde (...)."

16 "Il a été fidèle à un programme de philosophie non-spéculative et soupçonnait de la spéculation chez Husserl, d'autant plus chez Heidegger. Mais sa propre conception de l'ontologie' nest-elle pas précisément pour cela dépourvue d'un fondement indispensable? Il veut faire de lontologie; mais que veut dire 'être' chez Ingarden? Où prend-il ses mesures de ce qui est et n'est pas?" 
way he approaches aesthetics, with the works of art perceived as intentional, having a specific mode of existence. What such a perception triggers is that Ingarden is no longer interested in art as such - at least so it seems to Patočka. It becomes merely one of the many elements of the structure Ingarden strived to describe. "You, my friend, have perfectly described his texts on literary works; in themselves, they were of no interest to him, he was neither moved nor thrilled by these, as was the case with texts on art or music; they constitute examples of the modes of 'intentional being' - but what is it?"17 (Patočka 1971b).

Krońska appears to be moved by Patočka's remarks and in her next letter, she renders her theory of Ingarden's positivism exhaustive. "As for my text on Ingarden, I certainly do not deserve all this praise, which I owe to your friendship. I did not have much to say and that I did speak was solely with the intention to convey a simple message, yet such none of Ingarden scientists wrote nor would ever write. It is not still sharply defined, hence the subtitle 'Fragment.' It may well be that what constitutes a gap in his philosophy, a weaker point, precisely this 'Positivism,' equally unfamiliar to me, whether with or without quotation marks, results from what you wrote: that he does not ask about being as such"18 (Krońska 1971c). Krońska thinks that when related to existential engagement and responsibility for the theses advanced, the positivism gains on importance. "For me it is also a matter of courage. In philosophy, important as it was to Ingarden, he failed to accept all the risk it entails, he imposed some conditionalities to adjust to"19 (Krońska 1971c). To put it differently, here Ingarden's positivism meant for Krońska taking such an attitude towards reality, such as its reduction, that would allow for it to be easily studied, without being subject to its dangers, the feeling of being threatened or the feeling of anxiety. This idea, which finalizes considerations on the philosophy of Ingarden, encompasses all the remarks made already in the late 1940s. In the light of 1968 , however, these have taken a new, existential meaning.

17 "Vous avez parfaitement caractérisé ses essais sur l’œuvre littéraire; celle-ci ne l’intéressait pas pour elle-même, il n’en était pas intérieurement saisi et bouleversé, c'est tout comme ses essais sur l'œuvre plastique ou sur la musique; ce sont des exemples des modes d'être intentionnel' - mais qu'est-ce que c'est?"

18 "Grand merci de votre grande lettre du 23 octobre (elle a dû se croiser avec la mienne). En ce qui concerne mon essai sur Ingarden, je ne la mérite pas, c'est certain, et ne la dois quà votre amitié. Je n'avais pas grand chose à dire, et si j’ai néanmoins pris la parole, c'est uniquement pour dire une chose peut-être minime, mais qu'aucun des Ingardenologues n’a jamais dit et ne dira pas; ce n'est pas encore tout à fait explicite, d'où le sous-titre: 'fragment.' Il se peut que ce qui est dans sa philosophie un manque, une déficience, justement ce 'positivisme' qui m’est aussi étranger que le positivisme sans guillemets, vient de ce que vous dites: qu'il ne se pose pas la question de lêtre en tant que tel."

19 "Pour moi c'est aussi une question de - courage. La philosophie, si importante quelle fut pour lui, il ne l'a pourtant jamais accepté avec tous les risques qu’elle comporte, il lui avait posé certaines conditions et elle devait s'y tenir." 
Now, let's get back to Patočka. He seems to approve of Krońska's line of arguing, significant to him inasmuch as he perceives an analogy between the situation of Ingarden and his own - a Central-European philosopher, forced to face the difficulties related to living and composing in the reality of the Soviet bloc countries. "What you write about Ingarden, I am actively interested in all of it. I find myself in a situation analogous to his. I respect his careful and systematic work, clarity of analysis, attention to detail, and consequence. Yet, he is a thinker who has come to a standstill, he never fights; his criticism poses a mere correction of a copy. A marvellous professor. Not fond of poison hemlock, he does not see any reason a philosopher would want to have to do with it. Still, there are many things he could teach us" (Patočka 1971c). ${ }^{20}$

\section{Conclusion}

Returning to the question that was my point of departure in this article, it seems as Krońska, though lacking a scientific record of strictly phenomenological works, will go down in history as the first one to formulate a consistent critique of the phenomenology of Roman Ingarden. However, this criticism should be considered only as an indistinct outline of a positive program, whose impact or direct consequences for Polish philosophy are difficult to evaluate. Finally, we have to mention one of the last initiatives of Irena Krońska, who shortly before her death in 1974, made possible a philosophical exchange between young PhD student, $\mathrm{Kr}$ zysztof Michalski and Jan Patočka (see de Warren 2016, Starzyński 2018: 24-26). This exchange certainly had its consequences for the development of Polish philosophy and phenomenology, which should be examined in a separate study.

English translation by Aleksandra Wójcicka

Bibliography

Ingarden R., 1949, Letter to I. Krońska of 14 April 1949, III. 13132/2, The Archive of Irena and Tadeusz Kroński, National Library of Poland, Warszawa.

Ingarden R., 1960, L'homme et la nature [in:] Atti del XII Congresso Internazionale di Filosofia, Venezia 1958, vol. 2. Firenze: Sansoni, pp. 209-213.

\footnotetext{
20 "Ce que vous écrivez sur Ingarden m’intéresse vivement. Nous nous trouvons par rapport à lui dans une situation assez analogique. J'estime dans Ingarden le travail assidu, méthodique, clair de l'analyse, sa pénétration, son souci de conséquence. Mais c'est un penseur de tout repos qui au fond ne combat jamais; ses critiques, c'est de la correction de copies. Magnifique professeur. Mais il n’a aucun goût pour la ciguë, ni ne voit pourquoi la philosophie aurait quoi que ce soit à y faire. N’empêche qu'il nous apprend beaucoup de choses.'
} 
Ingarden R., 1963a, Z badań nad filozofia współczesną, Warszawa: PWN.

Ingarden R., 1963b, Letter to I. Krońska of 8 March 1963, III. 13132/2, The Archive of Irena and Tadeusz Kroński, National Library of Poland, Warszawa.

Ingarden R., 1967, Letter to I. Krońska of second half of December 1967, III. 13132/2, The Archive of Irena and Tadeusz Kroński, National Library of Poland, Warszawa.

Ingarden R., 1968a, Letter to I. Krońska of 12 July 1968, III. 13132/2, The Archive of Irena and Tadeusz Kroński, National Library of Poland, Warszawa.

Ingarden R., 1968b, Letter to I. Krońska of 23 September 1968, III. 13132/2, The Archive of Irena and Tadeusz Kroński, National Library of Poland, Warszawa.

Ingarden R., 1970, Co jest nowego w ostatniej pracy Husserla?, Studia Filozoficzne, nr 4, pp. 3-14.

Ingarden R., 1987a, Spór o istnienie świata, t. 1, Ontologia egzystencjalna, Warszawa: PWN. Ingarden R., 1987b, Książeczka o człowieku, Kraków: Wydawnictwo Literackie.

Krońska I., 1949, Review of Spór o istnienie świata, by R. Ingarden, Revue philosophique de France et de l'étranger, 139, pp. 219-225.

Krońska I., 1968, Notes on the letter of R. Ingarden to I. Krońska of 23 September 1968, III. 13132/2, The Archive of Irena and Tadeusz Kroński, National Library of Poland, Warszawa.

Krońska I., 1970a, Letter to M. Ingarden of 16 June 1970, III. 13132/2, The Archive of Irena and Tadeusz Kroński, National Library of Poland, Warszawa.

Krońska I., 1970b, Letter to J. Patočka of 5 July 1970, 5006/003, K44, The Jan Patočka Archive, Prague. Polish transl. by W. Starzyński [in:] Patočka J., Krońska I., Kroński T., Michalski K., 2018, Korespondencja Jana Patočki z Ireną Krońską i Krzysztofem Michalskim (wraz z listami Tadeusza Krońskiego), Warszawa: Wydawnictwo IFiS PAN, pp. 100-102.

Krońska I., 1971a, Roman Ingarden: Fragment retrospekcji, Twórczość, nr 10, pp. 86-94.

Krońska I., 1971b, Letter to J. Patočka of 3 August 1971, 5006/003, K59a, The Jan Patočka Archive, Prague. Polish transl. by W. Starzyński [in:] Patočka J., Krońska I., Kroński T., Michalski K., 2018, Korespondencja Jana Patočki z Ireną Krońska i Krzysztofem Michalskim (wraz z listami Tadeusza Krońskiego), Warszawa: Wydawnictwo IFiS PAN, pp. 126-128.

Krońska I., 1971c, Letter to J. Patočka of 14 November 1971; 5006/003, K64a, The Jan Patočka Archive, Prague. Polish transl. by W. Starzyński [in:] Patočka J., Krońska I., Kroński T., Michalski K., 2018, Korespondencja Jana Patočki z Irena Krońska i Krzysztofem Michalskim (wraz z listami Tadeusza Krońskiego), Warszawa: Wydawnictwo IFiS PAN, pp. 141-143.

Kroński T., 1933, Review of R. Ingarden, Das literarische Kunstwerk. Eine Untersuchung aus dem Gremgebiet der Ontologie. Logik und Literaturwissenschaft, Halle: Niemeyer 1931, Przegląd Filozoficzny, nr 4, pp. 387-391.

Kroński T., 1938, Czym jest dzieło literackie i jak je poznajemy, Ateneum, nr 4-5, pp. 680-685. Kroński T., 1939, Letter to J. Patočka of 2 February 1939, Složka "Korespondence Patočkovi přijatá," The Jan Patočka Archive, Prague. Polish transl. by W. Starzyński [in:] Patočka J., Krońska I., Kroński T., Michalski K., 2018, Korespondencja Jana Patočki z Irena Krońska i Krzysztofem Michalskim (wraz z listami Tadeusza Krońskiego), Warszawa: Wydawnictwo IFiS PAN, pp. 37-38. 
Kroński T., 1952, Świat w klamrach ontologii [O książce R. Ingardena "Spór o istnienie świata”], Myśl Filozoficzna, nr 1, pp. 318-331.

Kroński T., 1960, Faszyzm a tradycja europejska [in:] Rozważania wokół Hegla, Warszawa: PWN, pp. 275-346.

Krzemicka I., 1938, Poznámky k otázce literárního překladu, transl. from Polish by J. Patočka, Česká mysl, 34, pp. 301-312.

Krzemicka I., 1939, Letter to J. Patočka of 30 April 1939, Složka "Korespondence Patočkovi přijatá," The Jan Patočka Archive, Prague. Polish transl. by D. Sobota [in:] Patočka J., Krońska I., Kroński T., Michalski K., 2018, Korespondencja Jana Patočki z Irena Krońska i Krzysztofem Michalskim (wraz z listami Tadeusza Krońskiego), Warszawa: Wydawnictwo IFiS PAN, pp. 41-42.

Patočka J., 1970, Letter to I. Krońska of 17 July 1970, 5006/003, P45, The Jan Patočka Archive, Prague. Polish transl. by W. Starzyński [in:] Patočka J., Krońska I., Kroński T., Michalski K., 2018, Korespondencja Jana Patočki z Ireną Krońska i Krzysztofem Michalskim (wraz z listami Tadeusza Krońskiego), Warszawa: Wydawnictwo IFiS PAN, pp. 102-103.

Patočka J., 1971a, Letter to I. Krońska of 9 July 1971, 5006/003, P59, The Jan Patočka Archive, Prague. Polish transl. by W. Starzyński [in:] Patočka J., Krońska I., Kroński T., Michalski K., 2018, Korespondencja Jana Patočki z Ireną Krońska i Krzysztofem Michalskim (wraz z listami Tadeusza Krońskiego), Warszawa: Wydawnictwo IFiS PAN, pp. 124-126.

Patočka J., 1971b, Letter to I. Krońska of 23 October 1971, 5006/003, P64, The Jan Patočka Archive, Prague. Polish transl. by W. Starzyński [in:] Patočka J., Krońska I., Kroński T., Michalski K., 2018, Korespondencja Jana Patočki z Irena Krońska i Krzysztofem Michalskim (wraz z listami Tadeusza Krońskiego), Warszawa: Wydawnictwo IFiS PAN, pp. 139-141.

Patočka J., 1971c, Letter to I. Krońska of 21 November 1971, P65, The Jan Patočka Archive, Prague. Polish transl. by W. Starzyński [in:] Patočka J., Krońska I., Kroński T., Michalski K., 2018, Korespondencja Jana Patočki z Irena Krońska i Krzysztofem Michalskim (wraz z listami Tadeusza Krońskiego), Warszawa: Wydawnictwo IFiS PAN, pp. 143-147.

Patočka J., 1972, Zu Roman Ingardens Ontologie des malerischen Kunstwerks, Philosophische Perspektiven, 4, pp. 117-125. Polish transl. by I. Krońska: Patočka J., 1972, Uwagi o Romana Ingardena filozofii obrazu [in:] Fenomenologia Romana Ingardena, Warszawa: Instytut Filozofii i Socjologii Polskiej Akademii Nauk, pp. 262-275.

Starzyński W., 2018, Wstęp [in:] Patočka J., Krońska I., Kroński T., Michalski K., Korespondencja Jana Patočki z Ireną Krońską i Krzysztofem Michalskim (wraz z listami Tadeusza Krońskiego), Warszawa: Wydawnictwo IFiS PAN, pp. 7-27.

Warren N. de, 2016, Introduction. Letters between Jan Patočka and Krzysztof Michalski (1973-1976), The New Yearbook for Phenomenology and Phenomenological Philosophy, 14, Special Issue: The Philosophy of Jan Patočka. 